\title{
Long-term slow slip event detected beneath the Shima Peninsula, central Japan, from GNSS data
}

\author{
Akio Kobayashi* (1) and Takahiro Tsuyuki
}

\begin{abstract}
Long-term slow slip events (SSEs), the largest events among slow earthquakes, occur repeatedly along the Nankai Trough, southwest Japan. Their locations, near the locked zones of the plate interface responsible for great megathrust earthquakes in the Nankai Trough, suggest that these events influence conditions in this critical seismogenic region. Characterizing the spatiotemporal changes of long-term SSEs is important for understanding changes in the locked portions of the plate interface before major earthquakes. Two decades of observations by the global navigation satellite system along the Nankai Trough have detected no long-term SSEs in a large area beneath the Kii Peninsula. We report details of a long-term SSE detected in satellite navigation data from the Shima Peninsula, the easternmost part of the Kii Peninsula, from spring 2017 to autumn 2018. The estimated moment release from this event is equivalent to an earthquake of magnitude 6.4.
\end{abstract}

Keywords: Long-term slow slip event, Nankai Trough, Shima Peninsula, GNSS

\section{Introduction}

Slow earthquakes are typically observed in the transition zones between locked and creeping zones on plate boundaries (Obara and Kato 2016). The Nankai Trough plate interface, off the coast of and beneath southwest Japan (Fig. 1), is host to several types of slow earthquakes. Long-term slow slip events (SSEs), with durations of months or years, have been observed by using data from the global navigation satellite system (GNSS) in the Bungo Channel (Hirose et al. 1999), the Kii Channel (Kobayashi 2014), and the Tokai region (Ozawa et al. 2002) (see Fig. 1 for locations). Short-term SSEs, with durations measured in days (Obara et al. 2004), occur along with low-frequency tremor in a belt along the downdip side of the locked zone. Very low-frequency earthquakes, with predominant periods of tens of seconds, have been documented on both downdip and updip sides of the locked zone (Ishihara 2003; Obara and Ito 2005). Low-frequency tremor also occurs on the

*Correspondence: akobayas@mri-jma.go.jp

Meteorological Research Institute, 1-1 Nagamine, Tsukuba, Ibaraki

305-0052, Japan updip side of the locked zone (Sakai et al. 2007; Obana and Kodaira 2009). Among these slow earthquakes, longterm SSEs are the largest events, and they are located near the locked zone along the Nankai Trough, where future great megathrust earthquakes are postulated. Therefore, long-term SSEs may have a large influence on physical conditions around the locked zone.

In addition to the long-term SSEs already mentioned, small long-term SSEs have also been observed in and near the Nankai Trough (Kobayashi 2010; Takagi et al. 2016; Ozawa 2017). Kobayashi (2017) used GNSS observations to objectively detect long-term SSEs along the Nankai Trough and reported that they are not distributed homogeneously along the strike direction. In particular, no long-term SSE was detected during the first two decades of GNSS observations on the Kii Peninsula, including its easternmost tip, the Shima Peninsula (Fig. 1b). This paper reports a small long-term SSE that occurred beneath the Shima Peninsula during 2017 and 2018, the first detection of such an event from GNSS data. 


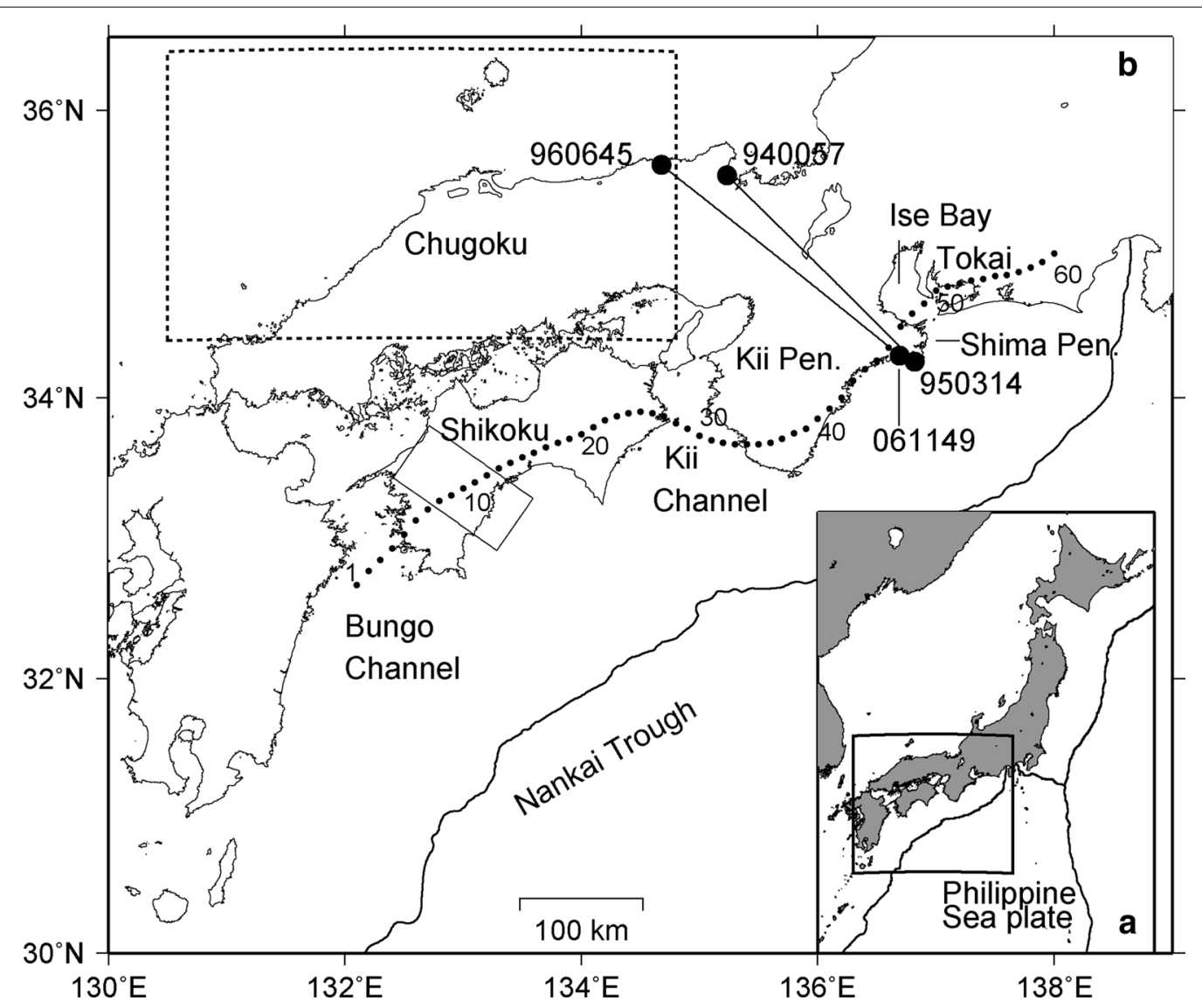

Fig. 1 Map of the study area in southwest Japan. a Location and plate tectonic setting. Heavy curves here and on the main map indicate plate boundaries. $\mathbf{b}$ Locations in the Nankai Trough study area. The dashed rectangle encloses the fixed region. Large numbered dots indicate GNSS stations. Heavy lines connecting two stations represent baselines for measurement of length changes. Small dots numbered 1-60 show the approximate location of the $25 \mathrm{~km}$ depth contour on the Nankai Trough subduction interface. The oblique rectangle in western Shikoku indicates an example of $100 \mathrm{~km} \times 50 \mathrm{~km}$ area centered on dot 10

\section{Data and methods}

\section{Detection of long-term SSEs by GNSS}

The GNSS Earth Observation Network System (GEONET) is operated in Japan by the Geospatial Information Authority of Japan (GSI). We used the GSI's F3 daily coordinate datasets (Nakagawa et al. 2009) from March 1996 to February 2019 for this study. In the GEONET F3 strategy, global positioning system (GPS) data are analyzed with Bernese GPS Software version 5.0, and the final orbit and Earth rotation parameters of the International GNSS Service (IGS) are used to estimate static daily coordinates (Ozawa 2017). Details can be found in Nakagawa et al. (2009) and Munekane (2010).

We applied the objective detection method described by Kobayashi (2017), extending the GNSS record in that paper from June 2017 to February 2019. The method is described briefly here. We first removed the steady-state or background surface displacement velocity, annual and semiannual variations, and offsets due to antenna/receiver replacement and earthquakes. Offsets due to antenna replacements were subtracted by using an offset dataset from GSI (http://mekira.gsi. go.jp/JAPANESE/corrf3o.dat). Coseismic offsets of large earthquakes were removed by calculating the difference in the 10-day means of the daily coordinates before and after each earthquake; however, no earthquake occurred that required the removal of coseismic offsets from the added months of data after the record analyzed by Kobayashi (2017). We then subtracted the common mode error (Wdowinski et al. 1997) of the fixed region (dashed rectangle in Fig. 1b) from the coordinates of all stations, in effect treating the entire rectangle region as fixed. The residual displacements are thus referred to as unsteady displacements. For each station, we calculated the component of motion in the direction $\mathrm{S} 55^{\circ} \mathrm{E}$, which is the direction of the upper 
plate with respect to the subducting Philippine Sea plate (N55 ${ }^{\circ}$ W; Miyazaki and Heki 2001).

The long-term SSEs along the Nankai Trough are centered at $25-30 \mathrm{~km}$ depth, on the upper surface of the subducting plate (e.g., Ozawa et al. 2002, 2013; Kobayashi 2014). We determined the positions of 60 points above the $25 \mathrm{~km}$ depth contour of the subducting plate (plate configuration of Hirose et al. 2008) at intervals of $0.1^{\circ}$ from longitude $132.1^{\circ} \mathrm{E}$ to $138.0^{\circ} \mathrm{E}$ (numbered points in Figs. $1 \mathrm{~b}$ and $2 \mathrm{a}$ ) and centered a $100 \mathrm{~km} \times 50 \mathrm{~km}$ rectangle on each point with its long axis oriented in the direction of plate subduction. For each rectangle, the component of motion in the direction $S 55^{\circ} \mathrm{E}$ was calculated from the mean of the horizontal components of GNSS stations within the rectangle.

Displacement components obtained by this procedure included the postseismic deformations associated with the March 11, 2011, Tohoku earthquake (M 9.0) and the September 5, 2004, off-Kii Peninsula earthquake (M 7.4). The postseismic component of the Tohoku earthquake was estimated by a logarithmic function using a mean time series of the stations, which had no unsteady displacements other than the postseismic deformation of the Tohoku earthquake. Assuming that the same time constant can be applied to the time series of displacement in the direction $\mathrm{S} 55^{\circ} \mathrm{E}$, the same logarithmic function was subtracted, fitting only the amplitude to the time series. The correction procedure was similar for the 2004 event, but the postseismic deformation overlapped the 2000-2005 long-term SSE in the Tokai region (Suito and Ozawa 2009). Therefore, assuming that the postseismic displacement was proportional to the coseismic displacement, the amplitude coefficient was estimated from the coseismic displacement of the stations near the epicenter.

At this point in the procedure, we evaluated the crosscorrelation between the displacement time series and a 3-year ramp function, which consisted of a linear slope over a 1-year period connecting flat slopes in the previous year and the following year. For more details, see Kobayashi (2017).

\section{Estimation of slip distribution}

The slip vector on the plate interface was estimated from the surface unsteady north-south and east-west horizontal displacements using the inversion technique of Yabuki and Matsu'ura (1992), with some modifications

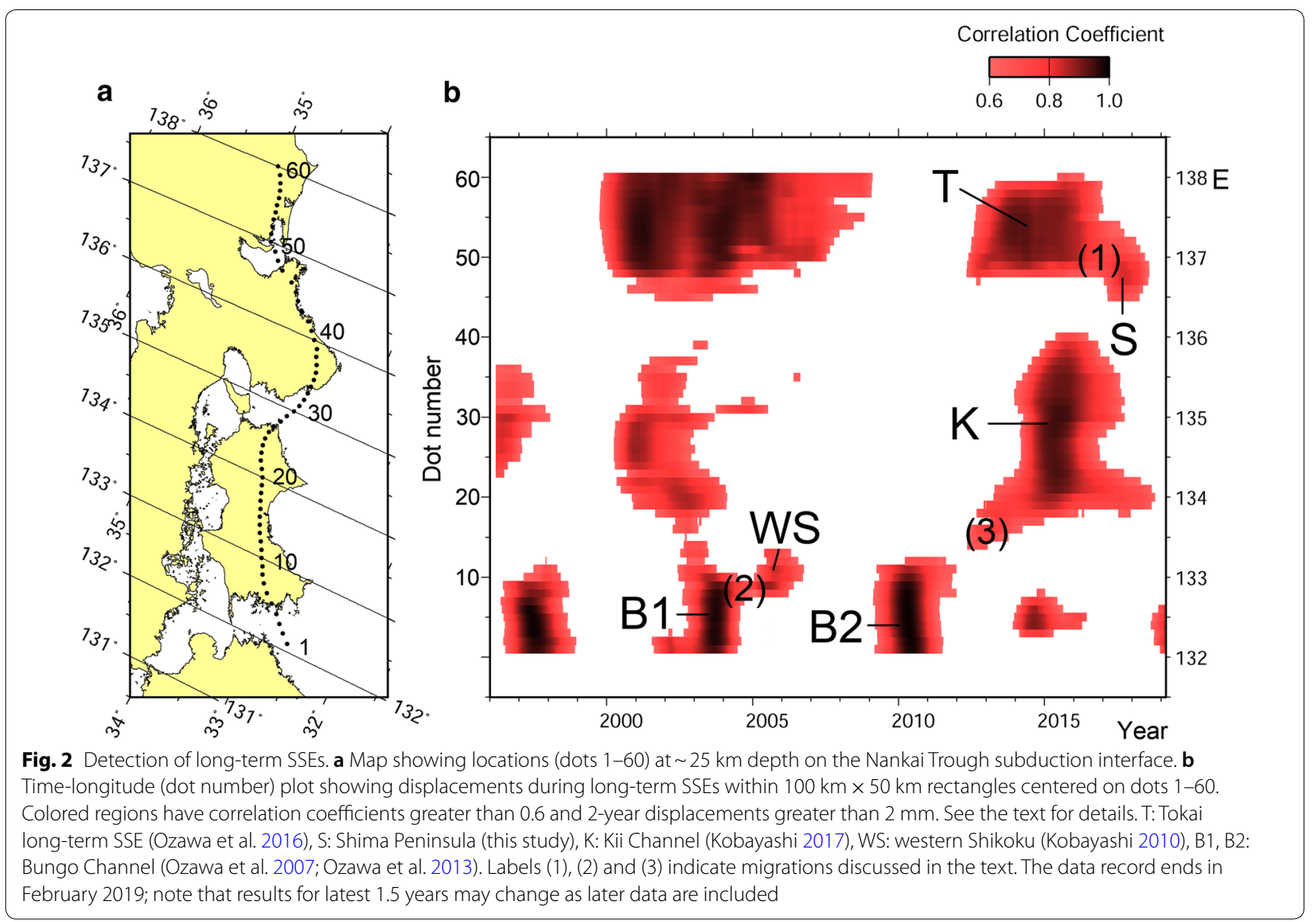


based on the formulation of Okada (1992). This inversion technique represents the slip distribution as a superposition of B-spline functions. In this study, slip vectors were represented by linear combinations of boxcar functions, and the values of coefficients were estimated by using a Bayesian model with a smoothness constraint for regularization. Scale factors were chosen for the covariance and smoothness parameters that minimized Akaike's Bayesian information criterion (ABIC, Akaike 1980). Slip vectors were calculated for a $12 \times 12$ grid of rectangular sources on the plate interface, using the plate interface configuration of Hirose et al. (2008). The grid intervals and rectangle dimensions were about $10.1 \mathrm{~km}$ along the strike of the Nankai Trough and about $9.8 \mathrm{~km}$ along the dip direction. The slip was set to zero outside the grid. Dip angles were derived from the plate configuration by using continuous curvature splines in tension (Smith and Wessel 1990). The slip direction was constrained within $45^{\circ}$ from the direction of plate subduction, using the nonnegative least squares method (Lawson and Hanson 1974).

\section{Results and discussion}

The spatiotemporal distribution of the correlation between displacement in the $555^{\circ} \mathrm{E}$ direction and the ramp function from March 1996 to February 2019 is shown in Fig. 2b, which displays periods when the correlation coefficient was greater than 0.6 and the 2-year displacement was greater than $2 \mathrm{~mm}$. Note that the results for latest 1.5 years may change as later data are included. After the Tokai long-term SSE (labeled $\mathrm{T}$ in Fig. 2b) subsided in 2016, displacement with high correlation migrated to the vicinity of the Shima Peninsula (labeled S) and continued there until July 2018. Note that the displacement with high correlation shown in Fig. 2b are not directly related to slip on the plate boundary beneath there. For example, high correlation related to 2000 Tokai long-term SSE extended to the Shima Peninsula. However, no slip was estimated in the Shima Peninsula (Ozawa et al. 2002). Displacements in the direction $\mathrm{S} 55^{\circ} \mathrm{E}$ and correlation coefficients between the displacement and the ramp function at a point near the Shima Peninsula are shown in Additional file 1: Figure S1.

Figure 3a shows the horizontal unsteady displacement on the Shima Peninsula from April 2017 to October 2018 with respect to the fixed region. In the procedure of the previous section, the postseismic deformation of the 2011 Tohoku earthquake is subtracted from the mean displacement time series for each grid, but it is not subtracted from the displacement of each station. To eliminate the postseismic deformation from the earthquake, displacement of each station from January 2016 to April 2017 was subtracted. According to the approximate function of postseismic deformation used by Kobayashi (2017), the postseismic displacement rates during these two periods differed by less than $1 \%$. The unsteady displacement consisted of southeastward horizontal movements of 7-8 mm; there was no systematic displacement

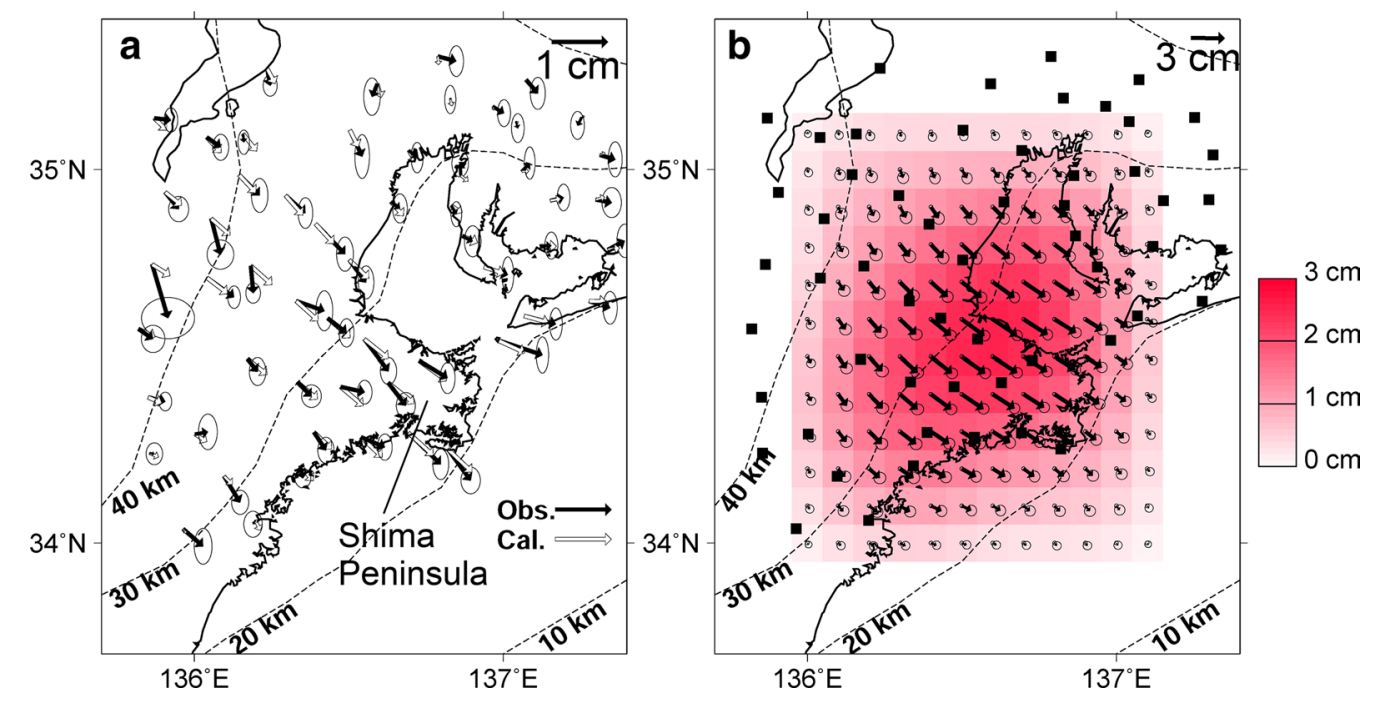

Fig. 3 Map of the Shima Peninsula showing horizontal unsteady displacement and estimated slip distribution. a Horizontal displacements for the period April 2017 to October 2018 used for estimating fault slip. Black arrows indicate observations, and white arrows indicate calculated values. Ellipses at the tips of the black arrows show standard deviations of the coordinates. $\mathbf{b}$ Estimated slip distribution on the plate interface. Arrows indicate the motion of the overriding plate with respect to the subducting Philippine Sea plate. Ellipses at the tips of the arrows indicate estimation errors. Solid squares are locations of GNSS stations. Dashed contours show the depth of the top of the subducting plate (Hirose et al. 2008) 
in the vertical component. Baseline lengths between two stations on the Shima Peninsula and two stations to the northwest showed slow extension of 7-8 $\mathrm{mm}$ from spring 2017 to autumn 2018 (Fig. 4). Because the unsteady displacement continued for more than a year and no other long-term slow slips occurred around this area during this period, it appears to correspond to a single longterm SSE.

The slip distribution on the plate interface, estimated from the unsteady displacements using the inversion technique, is shown in Fig. 3b. The maximum slip, about $3 \mathrm{~cm}$, was located beneath the Shima Peninsula. The plate interface at that location is about $25-30 \mathrm{~km}$ deep, which is consistent with the depths of other long-term SSEs along the Nankai Trough. The estimated moment magnitude corresponding to the total slip was 6.5 , assuming a rigidity of $40 \mathrm{GPa}$.

Long-term rate of moment release of the short-term SSEs along the Nankai Trough is roughly constant (Nishimura et al. 2013). However, recurrence interval of the short-term SSEs decreased during the longterm SSEs of the Bungo Channel and the Tokai region (Hirose and Obara 2005; Hiramatsu et al. 2008). Shortterm SSEs occurred around the Shima Peninsula, during this long-term SSE period and the steady-state period. Therefore, we confirm whether the short-term SSE has been activated during the long-term SSE of the Shima Peninsula. Ochi et al. (2016a, b, 2017a, b, 2018a, b, 2019) estimated rectangle faults of short-term SSEs using the strain, tilt and groundwater level data. We calculated displacements by the formulation of Okada (1992) using these parameters of the rectangle faults. We adopted the same period length just before the long-term slow slip period as the steady-state period. Maximum horizontal displacements on the Shima Peninsula caused by the short-term SSEs for the period of the long-term SSE (from April 2017 to October 2018) and the steady-state period (from October 2015 to

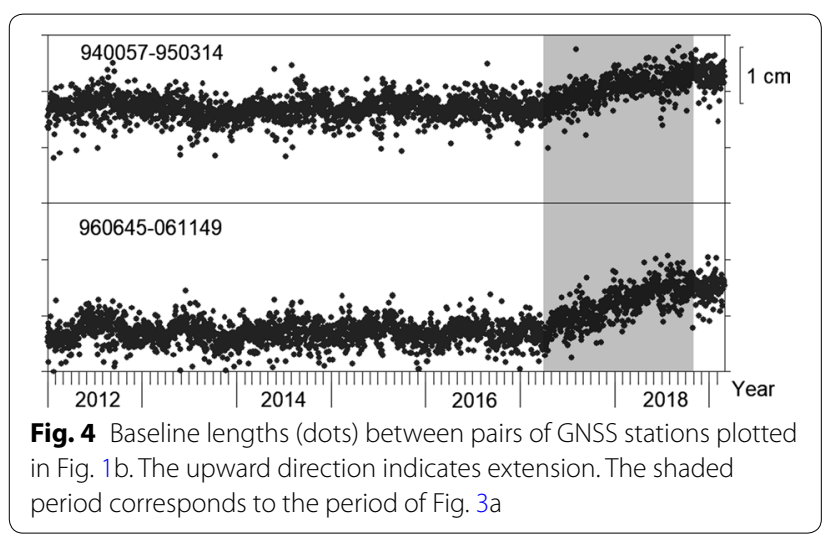

April 2017) were $7.0 \mathrm{~mm}$ and $4.5 \mathrm{~mm}$, respectively. The fault parameters of the short-term SSEs for each period are shown in Additional file 2: Tables S1 and S2. The short-term SSEs around the Shima Peninsula became active during the period of the long-term SSE; therefore, we estimated the contribution of the short-term SSE activation included in the estimated slip of the long-term SSE. The displacement due to the short-term SSE activity of the steady-state period has already been subtracted as a part of displacement velocity. Then, the contribution of the activated short-term SSEs during the long-term SSE period was $2.5 \mathrm{~mm}$. Therefore, remaining unsteady displacement is considered to be due to the long-term SSE. The estimated moment magnitude corresponding to the long-term SSE alone was 6.4. Thus, we report the first documentation of a longterm SSE on the Shima Peninsula.

This updated record of SSEs may have implications for the locked region of the plate interface. Figure $2 b$ shows a smooth connection of grid cells with moderate correlation (near 0.6) (labeled (1) in Fig. 2b) between the 20172018 long-term SSE documented here (labeled S) and the Tokai long-term SSE from 2013 to 2016 (labeled T). There are some similar connections between SSEs in the figure. For example, it shows a connection (labeled (2)) between the 2003 long-term SSE in the Bungo Channel (labeled B1) and the 2005 western Shikoku long-term SSE (labeled WS) (Kobayashi 2010; Takagi et al. 2016). Similar connection (labeled (3)) is also seen between the 2010 long-term SSE in the Bungo Channel (labeled B2) and the 2014-2016 long-term SSE in the Kii Channel (labeled K). Note that during the latter event, the area of highest correlation appears to have migrated through central and eastern Shikoku, where no long-term SSE have been detected in GNSS. If the areas of moderate correlation imply small amounts of slip on the plate interface, it may be that small slow slips are being transmitted. Simulations of the seismic cycles along the Nankai Trough based on a rate- and state-dependent friction law indicate that locked regions become smaller with time during the interseismic period (Hirose and Maeda 2013; Nakata et al. 2014). The weakening of coupling in the locked region may appear as new areas of slow slip as well as changes of the steady state. Ozawa et al. (2012) revealed a preceding aseismic slip of the 2011 Tohoku earthquake. Koulali et al. (2017) pointed out an increasing amplitude of the SSE toward the 2016 Te Araroa earthquake, New Zealand. The expansion of the long-term SSE slip area and the increase in slip amount may cause stress changes in the adjacent rocked zone and promote the occurrence of a large earthquake. To explore this issue further, it is important to characterize the spatiotemporal transitions of long-term SSEs. 


\section{Conclusion}

We used GNSS daily coordinate data to detect unsteady displacement on the Shima Peninsula, central Japan. This displacement represents the first long-term SSE to be observed on the Shima Peninsula from spring 2017 to autumn 2018. Horizontal unsteady displacement with respect to the fixed region showed southeastward movements of 7-8 $\mathrm{mm}$ on the Shima Peninsula during this SSE. Baseline lengths between stations on the Shima Peninsula and stations to the northwest indicated slow extension starting in 2017. The slip distribution on the plate interface, estimated using the inversion technique, indicates moment release beneath the Shima Peninsula equivalent to an earthquake with a moment magnitude of 6.4 .

\section{Additional files}

Additional file 1. Displacements in the direction $\mathrm{S} 55^{\circ} \mathrm{E}$ (top) and correlation coefficients between the displacement and the ramp function at a point (bottom). Displacement is the mean of displacements of stations (red dots) within the $100 \mathrm{~km} \times 50 \mathrm{~km}$ rectangle on the inset map.

Additional file 2. Fault parameters of the short-term slow slip events.

\section{Abbreviations}

GEONET: GNSS Earth Observation Network System; GNSS: global navigation satellite system; GPS: global positioning system; GSI: Geospatial Information Authority of Japan; SSE: slow slip event.

\section{Acknowledgements}

The GNSS F3 coordinate data and offset data were provided by the Geospatial Information Authority of Japan. MICAP-G software (Naito and Yoshikawa 1999), based on the formulation of Okada (1992), was used for calculating displacements, and GMT software (Wessel and Smith 1998) was used for figures. We referred to the source code of Yamamoto (2005). We thank two anonymous reviewers for their careful and constructive reviews.

\section{Authors' contributions}

AK analyzed the GNSS data and wrote most of the manuscript. TT modified the inversion software and helped with the preparation of the manuscript. Both authors read and approved the final manuscript.

\section{Funding}

This work was supported by the Meteorological Research Institute, Japan Meteorological Agency.

\section{Availability of data and materials}

The daily GNSS coordinate data are available from the GSI Web site (http:// terras.gsi.go.jp/). GNSS processed coordinate data used in this study are available from the corresponding author.

\section{Ethics approval and consent to participate}

Not applicable.

\section{Consent for publication}

Not applicable.

\section{Competing interests}

The authors declare that they have no competing interests.
Received: 12 February 2019 Accepted: 11 May 2019

Published online: 27 May 2019

\section{References}

Akaike H (1980) Likelihood and the Bayes procedure. In: Bernardo JM, De Groot MH, Lindley DV, Smith AFM (eds) Bayesian statistics. University Press, Valencia, pp 143-166

Hiramatsu Y, Watanabe T, Obara K (2008) Deep low-frequency tremors as a proxy for slip monitoring at plate interface. Geophys Res Lett 35:13. https ://doi.org/10.1029/2008GL034342

Hirose F, Maeda K (2013) Simulation of recurring earthquakes along the Nankai trough and their relationship to the Tokai long-term slow slip events taking into account the effect of locally elevated pore pressure and subducting ridges. J Geophys Res 118:4127-4144. https://doi.org/10.1002/ jgrb.50287

Hirose H, Obara K (2005) Repeating short- and long-term slow slip events with deep tremor activity around the Bungo channel region, southwest Japan. Earth Planets Space 57:961-972. https://doi.org/10.1186/BF03351875

Hirose H, Hirahara K, Kimata F, Fujii N, Miyazaki S (1999) A slow thrust slip event following the two 1996 Hyuganada earthquakes beneath the Bungo Channel, southwest Japan. Geophys Res Lett 26:3237-3240. https://doi. org/10.1029/1999GL010999

Hirose F, Nakajima J, Hasegawa A (2008) Three-dimensional seismic velocity structure and configuration of the Philippine Sea slab in southwestern Japan estimated by double-difference tomography. J Geophys Res 113:B09315. https://doi.org/10.1029/2007JB005274

Ishihara Y (2003) Major existence of very low frequency earthquakes in background seismicity along subduction zone of south-western Japan. AGU Fall Meeting Abstracts S41C-0107

Kobayashi A (2010) A small scale long-term slow slip occurred in the western Shikoku in 2005. J Seismol Soc Jpn 63:97-100. https://doi.org/10.4294/ zisin.63.97 (in Japanese)

Kobayashi A (2014) A long-term slow slip event from 1996 to 1997 in the Kii Channel, Japan. Earth Planets Space 66:9. https://doi. org/10.1186/1880-5981-66-9

Kobayashi A (2017) Objective detection of long-term slow slip events along the Nankai Trough using GNSS data (1996-2016). Earth Planets Space 69:171. https://doi.org/10.1186/s40623-017-0755-7

Koulali A, McClusky S, Wallace L, Allgeyer S, Tregoning P, D'Anastasio E, Benavente R (2017) Slow slip events and the 2016 Te Araroa Mw 7.1 earthquake interaction: Northern Hikurangi subduction, New Zealand. Geophys Res Lett 44:8336-8344. https://doi.org/10.1002/2017GL074776

Lawson CL, Hanson RJ (1974) Solving least squares problems. Prentice-Hall, Englewood Cliffs

Miyazaki S, Heki K (2001) Crustal velocity field of southwest Japan: subduction and arc-arc collision. J Geophys Res 106:4305-4326. https://doi. org/10.1029/2000JB900312

Munekane H (2010) On improving precision of GPS-derived height time series at GEONET stations. Bull GSI 58:39-46

Naito H, Yoshikawa S (1999) A program to assist crustal deformation analysis. J Seismol Soc Jpn 52:101-103. https://doi.org/10.4294/zisin1948.52.1_101 (in Japanese)

Nakagawa H, Toyofuku T, Kotani K, Miyahara B, Iwashita C, Kawamoto S, Hatanaka Y, Munekane H, Ishimoto M, Yutsudo T, Ishikura N, Sugawara Y (2009) Development and validation of GEONET new analysis strategy (Version 4). J Geogr Surv Inst 118:1-8 (in Japanese)

Nakata R, Hyodo M, Hori T (2014) Possible slip history scenarios for the Hyuganada region and Bungo Channel and their relationship with Nankai earthquakes in southwest Japan based on numerical simulations. J Geophys Res 119:4787-4801. https://doi.org/10.1002/2014JB010942

Nishimura T, Matsuzawa T, Obara K (2013) Detection of short-term slow slip events along the Nankai Trough, southwest Japan, using GNSS data. J Geophys Res 118:3112-3125. https://doi.org/10.1002/jgrb.50222

Obana K, Kodaira S (2009) Low-frequency tremors associated with reverse faults in a shallow accretionary prism. Earth Planet Sci Lett 287:168-174. https://doi.org/10.1016/j.epsl.2009.08.005

Obara K, Ito Y (2005) Very low frequency earthquakes excited by the 2004 off the Kii peninsula earthquakes: a dynamic deformation process in the 
large accretionary prism. Earth Planets Space 57:321-326. https://doi. org/10.1186/BF03352570

Obara K, Kato A (2016) Connecting slow earthquakes to huge earthquakes. Science 353(6296):253-257. https://doi.org/10.1126/science.aaf1512

Obara K, Hirose H, Yamamizu F, Kasahara K (2004) Episodic slow slip events accompanied by non-volcanic tremors in southwest Japan subduction zone. Geophys Res Lett 31:L23602. https://doi.org/10.1029/2004GL0208 48

Ochi T, Itaba S, Koizumi N, Matsumoto N, Kitagawa Y, Takeda N, Kiguchi T, Kimura H, Kimura T, Matsuzawa T, Shiomi K (2016a) Short-term slow slip events in the Tokai area, the Kii Peninsula and the Shikoku District, Japan (from May 2015 to October 2015). Rep Coord Comm Earthq Pred 95:255-264 (in Japanese)

Ochi T, Itaba S, Matsumoto N, Kitagawa Y, Takeda N, Kiguchi T, Kimura H, Kimura T, Matsuzawa T, Shiomi K (2016b) Short-term slow slip events in the Tokai area, the Kii Peninsula and the Shikoku District, Japan (from November 2015 to April 2016). Rep Coord Comm Earthq Pred 96:255-270 (in Japanese)

Ochi T, Itaba S, Matsumoto N, Kitagawa Y, Takeda N, Kiguchi T, Kimura H, Kimura T, Matsuzawa T, Shiomi K (2017a) Short-term slow slip events in the Tokai area, the Kii Peninsula and the Shikoku District, Japan (from May 2016 to October 2016). Rep Coord Commun Earthq Pred 97:242-253 (in Japanese)

Ochi T, Itaba S, Matsumoto N, Kitagawa Y, Takeda N, Kiguchi T, Kimura H, Kimura T, Matsuzawa T, Shiomi K (2017b) Short-term slow slip events in the Tokai area, the Kii Peninsula and the Shikoku District, Japan (from November 2016 to April 2017). Rep Coord Commun Earthq Pred 98:263-274 (in Japanese)

Ochi T, Itaba S, Matsumoto N, Kitagawa Y, Takeda N, Kiguchi T, Kimura H, Kimura T, Matsuzawa T, Shiomi K (2018a) Short-term slow slip events in the Tokai area, the Kii Peninsula and the Shikoku District, Japan (from May 2017 to October 2017). Rep Coord Commun Earthq Pred 99:243-257 (in Japanese)

Ochi T, Itaba S, Matsumoto N, Kitagawa Y, Takeda N, Kiguchi T, Kimura H, Kimura T, Matsuzawa T, Shiomi K (2018b) Short-term slow slip events in the Tokai area, the Kii Peninsula and the Shikoku District, Japan (from November 2017 to April 2018). Rep Coord Comm Earthq Pred 100:165-182 (in Japanese)

Ochi T, Itaba S, Matsumoto N, Kitagawa Y, Takeda N, Kiguchi T, Kimura H, Kimura T, Matsuzawa T, Shiomi K (2019) Short-term slow slip events in the Tokai area, the Kii Peninsula and the Shikoku District, Japan (from May 2018 to October 2018). Rep Coord Comm Earthq Pred 101 (in press) (in Japanese)

Okada Y (1992) Internal deformation due to shear and tensile faults in a halfspace. Bull Seismol Soc Am 82(2):1018-1040

Ozawa S (2017) Long-term slow slip events along the Nankai trough subduction zone after the 2011 Tohoku earthquake in Japan. Earth Planets Space 69:56. https://doi.org/10.1186/s40623-017-0640-4

Ozawa S, Murakami M, Kaidzu M, Tada T, Sagiya T, Hatanaka Y, Yarai H, Nishimura T (2002) Detection and monitoring of ongoing aseismic slip in the Tokai region, central Japan. Science 298:1009-1012. https://doi. org/10.1126/science.1076780

Ozawa S, Suito H, Imakiire T, Murakami M (2007) Spatiotemporal evolution of aseismic interplate slip between 1996 and 1998 and between 2002 and 2004, in Bungo channel, southwest Japan. J Geophys Res 112:B05409. https://doi.org/10.1029/2006JB004643

Ozawa S, Nishimura T, Munekane H, Suito H, Kobayashi T, Tobita M, Imakiire T (2012) Preceding, coseismic, and postseismic slips of the 2011 Tohoku earthquake, Japan. J Geophys Res 117:B07404. https://doi. org/10.1029/2011JB009120

Ozawa S, Yarai H, Imakiire T, Tobita M (2013) Spatial and temporal evolution of the long-term slow slip in the Bungo Channel, Japan. Earth Planets Space 65:67-73. https://doi.org/10.5047/eps.2012.06.009

Ozawa S, Tobita M, Yarai H (2016) A possible restart of an interplate slow slip adjacent to the Tokai seismic gap in Japan. Earth Planets Space 68:54. https://doi.org/10.1186/s40623-016-0430-4

Sakai S, Yamada T, Shinohara M, Kanazawa T, Takanami T, Hino R, Shimizu H, Obana K, Kodaira S, Kaneda Y (2007) Long duration tremor at off KiiPeninsula by ocean bottom seismometers. In: Japan Geoscience Union Meeting 2007 Abstract, S229- P007, Japan Geoscience Union, Chiba, Japan, 19-24 May 2007

Smith WHF, Wessel P (1990) Gridding with continuous curvature splines in tension. Geophysics 55:293-305. https://doi.org/10.1190/1.1442837

Suito H, Ozawa S (2009) Transient crustal deformation in the Tokai district-The Tokai slow slip event and postseismic deformation caused by the 2004 off southeast Kii peninsula earthquake. J Seismol Soc Jpn 61:113-135. https://doi.org/10.4294/zisin.61.113 (in Japanese with English abstract)

Takagi R, Obara K, Maeda T (2016) Slow slip event within a gap between tremor and locked zones in the Nankai subduction zone. Geophys Res Lett 43:1066-1074. https://doi.org/10.1002/2015GL066987

Wdowinski S, Bock Y, Zhang J, Fang P, Genrich J (1997) Southern California Permanent GPS geodetic array: spatial filtering of daily positions for estimating coseismic and postseismic displacements induced by the 1992 Landers earthquake. J Geophys Res 102:18057-18070. https://doi. org/10.1029/97JB01378

Wessel P, Smith WHF (1998) New, improved version of the Generic Mapping Tools released. EOS Trans Am Geophys Union 79:579. https://doi. org/10.1029/98EO00426

Yabuki T, Matsu'ura M (1992) Geodetic data inversion using a Bayesian information criterion for spatial distribution of fault slip. Geophys J Int 109:363-375. https://doi.org/10.1111/j.1365-246X.1992.tb00102.x

Yamamoto T (2005) Development of a software to assist crustal deformation analysis. Tech Rep Meteorol Res Inst 46:156-159. https://doi.org/10.11483 /mritechrepo.46 (in Japanese)

\section{Publisher's Note}

Springer Nature remains neutral with regard to jurisdictional claims in published maps and institutional affiliations.

\section{Submit your manuscript to a SpringerOpen ${ }^{\circ}$ journal and benefit from:}

- Convenient online submission

- Rigorous peer review

- Open access: articles freely available online

- High visibility within the field

- Retaining the copyright to your article

Submit your next manuscript at $\boldsymbol{\nabla}$ springeropen.com 